Article

\title{
A Handshake between Markets and Hierarchies: Geese as an Example of Successful Collaborative Management of Ecosystem Services
}

\author{
Magnus Tuvendal ${ }^{1}$ and Johan Elmberg ${ }^{2, *}$ \\ Received: 23 October 2015; Accepted: 20 November 2015; Published: 2 December 2015 \\ Academic Editor: Douglas H. Constance \\ 1 Stockholm Resilience Centre, Stockholm University, Stockholm SE-106 91, Sweden; \\ magnus.tuvendal@gmail.com \\ 2 Division of Natural Sciences, Kristianstad University, Kristianstad SE-291 88, Sweden; Johan.Elmberg@hkr.se \\ * Correspondence: Johan.Elmberg@hkr.se; Tel.: +46-70-266-6450
}

\begin{abstract}
An important task in research about natural resource management is to communicate the utility of different approaches from various settings. Using ecosystem services as a conceptual frame, we study a local solution to alleviate goose-human conflicts in an agricultural region in Sweden. Increasing goose numbers and crop damage led to the foundation of a goose management group (GMG), comprising landowners, farmers, hunters, ornithologists, conservation NGOs, and local and county level administration. The GMG was not given any formal or legal authority. We asked: is this management solution successful? Which problems can be solved and which remain? Can the GMG stand as a model for management of other species and in other landscapes? We interviewed present members of the GMG and analyzed minutes from its meetings. We found that the GMG has autonomy to self-organize and shows adaptive capacity over time in handling variability and complexity in its socio-ecological system. This makes the GMG a sustainable solution for local management of a resource in which goose population growth and legislation are decided at other (national or international) levels. We assessed what constitutes perceived success and found that GMG is geared toward "mediation of opposing preferences" by establishing a figurative handshake between stakeholders. By comparing how four general challenges in ecosystem service management align with formative attributes of the GMG, we discuss in which ways this management solution is applicable to other ecosystem services in other contexts.
\end{abstract}

Keywords: collaborative management; ecosystem service; geese; governance; socio-ecological systems; stakeholder; sustainability

\section{Introduction}

\subsection{Governance of Ecosystem Services}

The concept "ecosystem service" (hereafter "ES") is increasingly used in science and policy-making, at a variety of scales and in different organizational contexts. Its appeal, for scholars and practitioners alike, is that it promises to enhance society's ability to sustainably use and govern natural resources. This ability can be enhanced by better understanding how to identify ES and how services emerge from ecology [1,2], by advances in mapping of ES relative to what resources are at hand $[3,4]$, and by increased understanding of how people value ES [5,6]. To capture and mainstream these values into economic instruments has been a major strand of ES research [7]. However, as pointed out in the TEEB synthesis report [8] "... in more complex situations involving multiple ecosystems and services, and/or plurality of ethical or cultural convictions, monetary valuations may 
be less reliable or unsuitable. In such cases, simple recognition of value may be more appropriate". A recent review of the process of making management decisions for ES first points out that the scientific literature is comparatively rich with work on how to quantify and map ES [9], while, secondly, observes that the three least-addressed core steps in a decision-making process for ES (as conceptualized by the authors) are "making management decisions", "performance measures" and "setting objectives through stakeholder consultation". The review concludes that study of deliberative and participatory methods could aid in identifying opportunities and constraints for effective and sustainable management of ES.

The ES concept rests on the presumption that different ES have properties in common and, thus, can fruitfully be captured under such an umbrella concept. This implies that there may be significant opportunities for cross-case and cross-sectorial learning from stories of success, and failures, in management of a particular ES or set of services. This is not to be confused with "blueprint thinking" [10] but does imply that there are substantial commonalities between different ES and that insights from management of different ES may have much to offer each other. Consequently, an important task in ES research is to find and present cases of successful management from various settings. In this article we contribute with one such case study, exploring management of geese in an agricultural landscape, and discussing both its local effectiveness and how it addresses general challenges in ES management.

\subsection{Challenges in Governing Ecosystem Services}

An ES approach in management demands a systemic perspective, and it challenges reductionism and compartmentalization as strategies for effective problem solving [11,12]. Indeed, there are several challenges in governing ES sustainably. Some are specific for particular ES and contexts, but there are also challenges of more general nature. As a basis for evaluating the generalizability of a particular management solution, the present case study, we highlight four such issues following Muradian and Rival [13]:

Trade-offs: management options that increase the generation of one ES may lead to a decrease in the generation of another. This forms the basis for the classic conflict between biodiversity conservation and intensive agriculture or forestry [14,15].

Opposing preferences: people give different weight to a certain ES and prioritize differently even when having the same understanding of consequences of an action [16]. This is what perpetuates the conflict between stakeholders, even when all the facts are known.

Spatial and temporal variability: ES have spatial and temporal structure, meaning that service generation and the corresponding well-being from use are subject to natural variability found in ecosystems. In other words, their availability and predictability vary over time and space. Moreover, natural variation in time and space is often dampened or exacerbated by anthropogenic influence. This also means that production and use of ES can be significantly separated from each other in time and space [2,17].

Complexity: An ES connects ecosystems with social systems, both of which are complex structures where elements are interrelated in such ways that properties of the systems cannot be understood by study of the elements in isolation. Societal responses in management and governance can be to ignore this complexity (e.g., by misplaced command and control solutions [18]), to try to reduce the complexity of the challenge at hand (e.g., by reductionist approaches and implementation of piecemeal solutions), or by matching complexity with complex design in management and governance arrangements [19].

Most of the above general challenges in ES management are well, widely, and richly illustrated in the management of geese. 


\subsection{Goose Management As an Ecosystem Service Study System}

Harvested wild species provide obvious ES, for example in the form of meat for consumption ("provisioning services" sensu Millennium Ecosystem Assessment [20]). Among these species, ungulates and game birds offer many examples of how such ES can be managed. This is an arena where "adaptive co-management" [21-23] has gained increased popularity in recent decades. This is a management approach that combines features of collaborative management, such as shared responsibility and power among stakeholders, with those of adaptive management where learning from experience is emphasised [24].

However, there is a general tendency in the management of game-related ES- "modern adaptive" as well as "old school non-/pre-adaptive" management-to manoeuver in a simplistic and reductionist landscape in the sense that limited geographical areas and one species at a time are considered (but see [25] for an example of the opposite).

Recently, ES (and some "disservices") of geese and other waterbirds were subject to a comprehensive review illustrating the multi-faceted and important roles these birds have in terrestrial as well as aquatic ecosystems [26]. Across much of the northern hemisphere geese occur in seasonally variable assemblages of species with largely overlapping resource utilization. These guilds often change in composition between seasons and they are, thus, dynamic in the spatial and temporal sense described above. Moreover, most northern hemispheric geese are medium- to long-distance migrants, meaning that ES and disservices pertaining to them, and associated stakeholders, are found in the different countries within their flyways. ES and disservices provided by one species are often the same in closely related species and in co-occurring species of the same guild. This makes management of ES related to geese a multi-species issue.

Goose management is, in other words, set in anything but a simplistic landscape. Rather, it is an ideal model to address all four general problems in ES management outlined above.

There is a long tradition of harvesting wild geese and, until recently, populations of several species were low due to overharvest and habitat loss. In the last few decades this picture has changed dramatically in several cases, notably in the North American Snow goose (Chen caerulescens) and the Canada goose (Branta canadensis), and in the European Greylag goose (Anser anser), Pink-footed goose (Anser brachyrhynchus), and Barnacle goose (Branta leucopsis). All of these species have undergone unprecedented population increases, leading to degradation of natural ecosystems and increased conflict with human interests. Arguably, the goose-human conflict has reached the same magnitude as that for big predators (a Google search delivered 10.7 million hits for ("goose" "conflict") versus 14.5 million hits for ("wolf" "conflict"), 2014-04-24). Needless to say, this constitutes a monumental management challenge and there is a strong sentiment in North America and Europe that goose-related problems are addressed "too little and too late".

\subsection{Objective}

The objective of this paper is to understand, and critically evaluate the outcome from, a local organizational solution to alleviate goose-human conflicts in a highly productive agricultural region in southern Sweden. We seek to understand: is this management solution successful? Which problems can be solved and which remain? Can this solution stand as a model for management of other species and in other landscapes?

We do this by studying the origin and working methods of the Goose Management Group of North-Eastern Scania (hereafter "GMG") based on interviews of its present members and minutes from its meetings. We then use the GMG case to address the four general challenges of ES management described above. 


\section{Background}

\subsection{The Landscape and Its Stakeholders and Actors}

We here understand actor as someone who can influence Goose management and stakeholder as someone who is influenced by goose management. These roles may overlap.

The GMG operates in the flat lowlands around the city of Kristianstad in North-Eastern Scania, Sweden's southernmost province. Soils are sandy or clayey, the growing season is long, and agriculture is much diversified. Goose grazing on farmland is sometimes non-destructive, but when crop damage occurs it varies by season and site; in summer a wide range of crops are concerned (almost exclusively by Greylag geese), whereas damage in other seasons is chiefly on sugar beets, potatoes, rape, fall-sown cereals, and on meadowland (Greylag goose, Bean goose (Anser fabalis), and Canada goose are the main culprits, but lately also Barnacle goose).

The area has some major lakes, where geese rest at night (all species) and breed in summer (Greylag goose, Canada goose). Unwanted eutrophication and disease transmission by geese may be an issue here. The landscape in North-Eastern Scania is dominated by agriculture, wetlands and built-up areas. There has not been any significant change in land use during the last 20 years, but the acreage of fall-sown (winter-green) crops has increased. Important to the present study and the work of GMG is also that large parts of the area sit within the Kristianstads Vattenrike Biosphere Area. Like other UNESCO-endorsed "Man and Biosphere" reserves it serves as a model area for conservation and sustainable resource use. Consequently, the GMG operates in an area where a lot of baseline information about biodiversity, natural resources, and resource use are available, even to the extent that some of these have been studied explicitly within the paradigm of ES [27-32].

Another important piece of background information is that most stakeholders on the Swedish game management arenas are formally organized in various ways. As a general rule, birdwatchers, conservationists, hunters, and farmers belong to organizations that have a hierarchical three-level structure; local clubs belong to a county/province level chapter within the same organization, which in turn belongs to a national organization.

\subsection{The Geese}

No less than 10 goose taxa occur on a regular basis (Supplementary Material, Table S1) in the region where the GMG operates. Two are extremely rare in the area (Red-breasted goose (Branta ruficollis) and the Lesser white-fronted goose (Anser erythropus)), and for them the local management challenge is to protect these globally endangered birds from disturbance and accidental mortality during rare appearances. The Brent goose (Branta bernicla) is a common transient migrant that occasionally stops to stage in the area, but only in very limited numbers on farmland. It does not cause any measurable damage and it is not hunted, thus not in focus for management other than protection. The remaining seven taxa, however, spend much time on farmland and do most of their foraging in such habitats, where they often form mixed multi-species flocks. Five of these taxa belong to the genus Anser. All these are grey-brown birds that are usually not recognized as separate species by other than ornithologists and hunters.

One species, the Greylag goose, used to be migratory and a scarce breeder only in the study area, but it has become abundant the year around. The four remaining Anser geese do not breed locally, but occur from October to March, and they increasingly remain through the heart of the winter. One of these, the Pink-footed goose, is very scarce (peak counts $<100$ birds) and the management challenge is rather to protect them from being accidentally shot. The White-fronted goose is also scarce (peak counts $<1000$ birds) in most years, but can occur in larger numbers at times.

There are two Bean goose taxa, which were up until recently not monitored separately; historically the Taiga bean goose (Anser (fabalis) fabalis) has been the most abundant goose in the area during the non-breeding season. The Tundra bean goose (Anser (fabalis) serrirostris) on the other hand, still has a poorly-known status in the area; in some years a mere handful is reported and in others there can be 
thousands. Both Bean goose taxa have a hunting season. The final two species, the Canada goose and the Barnacle goose are nowadays abundant in the area, and both increasingly stay through the winter. The Canada goose is introduced, but it has been breeding in the area for more than 30 years and it does have a hunting season. The Barnacle goose was long a scarce transient migrant only, but is now a local breeder and it has increased tremendously in numbers as a staging bird in fall and spring, lately also in winter. Barnacle geese can be hunted locally by permit, but this is still very rarely done.

As is obvious from the above, goose management in North-Eastern Scania is a complex task from the very start. In addition to each species having its annual temporal pattern of abundance, large between-year variations in numbers due to the severity of winter affect the conflict/management setting (cf. Figure 1). Making the issue even more challenging, the Whooper swan (Cygnus cygnus) and the Common crane (Grus grus) are also part of the picture, as they both forage extensively on farmland in the region and occur in large numbers.

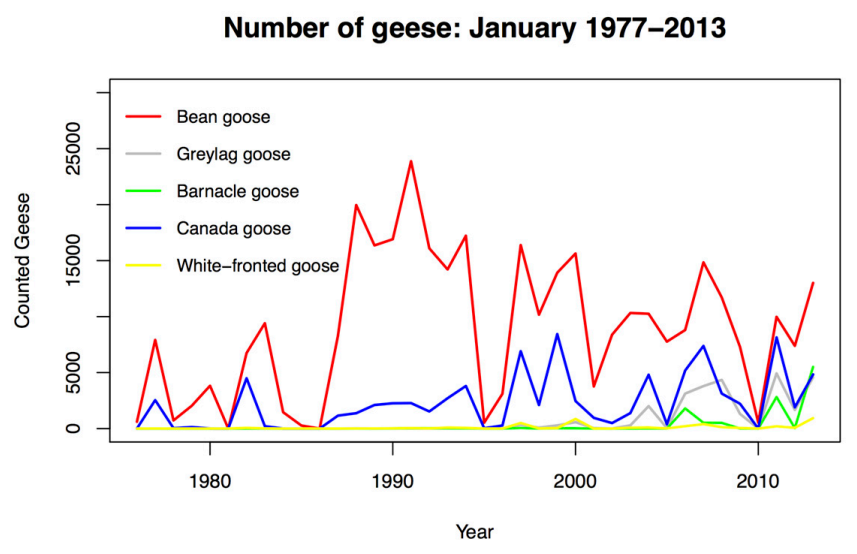

(a)

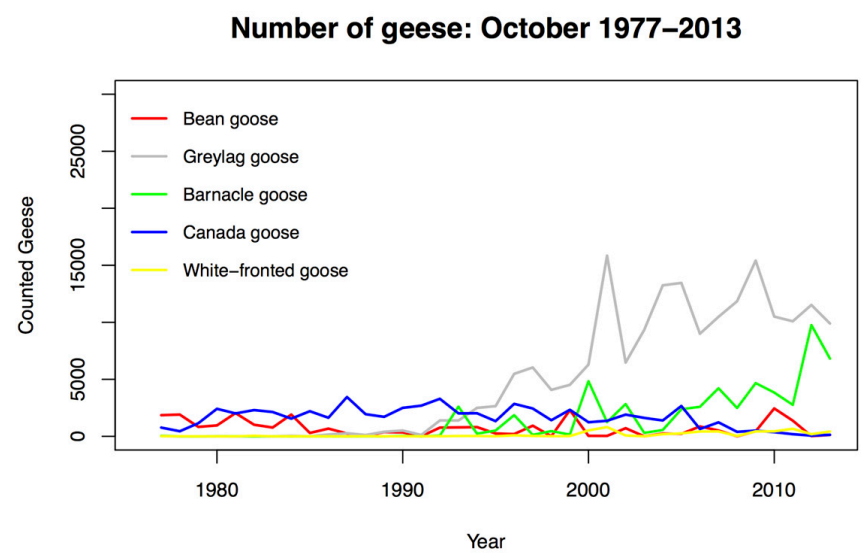

(b)

Figure 1. Numbers in the GMG (Goose Management Group of North-Eastern Scania) area of the five most numerous goose species by year (January top, and, October bottom). Displayed are Bean Goose (Anser fabalis), Barnacle goose (Branta leucopsis), Greylag goose (Anser anser), Canada goose (Branta canadensis), and White-fronted goose (Anser albifrons). Note the dramatic increase in numbers of Greylag and Barnacle geese in October during the last 20 years, which is concomitant with a significant increase in goose grazing damage on fall-sown winter-green crops. Note also the erratic and large between-year variation in numbers of most species in January, illustrating the necessity of feedback and adaptive responses in the governance system. Count data (monthly) from the bird club of Northeastern Scania [33]. 


\section{Methods}

\subsection{Meeting Minutes}

The GMG has a history that spans back to 2002. All available minutes from 23 meetings of the group were subject to analysis. The documents were coded following an inductive coding scheme [34] where passages of text were grouped into categories/codes. Data about who were present at meetings were also drawn from the meeting minutes.

\subsection{Interview-Conveners of the $G M G$}

An hour-long semi-structured interview [35] of the present chairmen and conveners of GMG (Hans Cronert and Anders Hallengren, employed by the County Administrative Board of Scania) was carried out in December 2013. The purposes were to get a broader and deeper picture of how GMG was founded and developed, and to document its past and present working methods when in session and in between meetings. HC has been part of the GMG since the start, whereas AH has been a convening member for the last two years.

The conveners were also given the opportunity to comment on the text about the history of the GMG at a later stage of the process, in order to avoid factual errors and address misunderstandings (see Results).

\subsection{Interviews-Present Members of the GMG}

To evaluate the performance, abilities, and success of the GMG, all of its current members, in total 16 respondents, were subjected to a structured interview [35] over the phone (with the exception of two respondents, who gave their answers in written form). Questions were read to the respondent, clarifications made when necessary, and the answers were written down. Each answer was mirrored back to the respondent for confirmation before moving to the next question. The 20 questions (Supplementary material, text file S2) were grouped into four themes: the success and abilities of the group, the challenges and limitations of the group, how people outside the group perceive it, and the how the group has evolved over time. The answers were subjected to inductive coding [34] for analysis. How actively and vigorously members of the GMG have represented their respective stakeholder groups was not explored in this study.

\section{Results}

\subsection{History}

In the early 1990's the Kristianstad municipality administration and the County Administrative Board of Scania initiated cooperation with landowners at the larger lakes around Kristianstad in order to restore previously extensive areas of shoreline meadows by removing bushes and reinstating cattle grazing. The main motive for this initiative was conservation of fauna and flora particular to this habitat. From the start it was obvious that these ambitions would be successful only if landowners and authorities developed a trustful cooperation and if win-win situations for conservation and agriculture could be achieved.

The latter was largely accomplished, so that informal communication channels between many landowners (mainly farmers) and authorities were in place in the late 1990s, when an increasing number of staging cranes began to cause significant damage in spring, mainly to freshly-sown barley. This prompted the municipality administration and the County Administrative Board to coordinate an informal advisory and discussion group with the objective to reduce conflict created by cranes. This "crane group" comprised ca. 10 people; farmers, ornithologists, conservationists, representatives from the municipality government, and officials on the County Administrative Board.

Around the year 2000 several farmers in the area felt that crop damage by increasing goose populations had become such a problem that action was needed. Damage by cranes was, after all, 
limited in space and time, and it was a widely held opinion, at this time, that goose damage would soon become a more serious problem than were the cranes. In response to this development, the already-operating crane group was given a wider mandate and subsequently re-moulded into the GMG. With geese added to the picture, so were representatives for hunters' interests (cranes are not hunted, but there is a hunting season for several of the goose species) and a wider range of landowners (e.g., large estates with commercial hunting activities and private farmers experiencing serious crop damage by geese).

Officials at the County Administrative Board and the Kristianstads Vattenrike Biosphere Area headed the transformation of the crane group into GMG, and invited new members in order to achieve a stakeholder representation that corresponded better to the broadened mandate (see "Working procedures", below). At a personal level, new members were selected based on the above criteria or their possessing key knowledge (e.g., goose expertise and experience of crop damage). In this selection process less pragmatic ("rigid") personalities were avoided if possible. This early GMG had about 20 members, of which 12-15 were to become regular attendees at its meetings.

The birth of the GMG was not only a response to farmers' initiative; it was also a pragmatic step to build a reference group around a local management plan then in progress for Greylag geese. Although formally published by the County Administrative Board [36] this plan came to rely heavily on contributions from the newly instated GMG. The original crane group as well as the early GMG had an informal official status, by most seen as a list of people with whom to discuss. However, the process leading to the Greylag goose management plan raised demands to formalize the group in terms of members, meetings, sendlists, etc.

From the onset, the coordinators at the County Administrative Board wanted to create an arena for discussion and information exchange, and there was never any ambition to create a group with a formal jurisdiction (interview, conveners). Neither was there any explicit ambition from the start to actually regulate goose populations at or below a certain level (interview, conveners; ([36], pp. 32-33). At the same time, the Greylag goose management plan and the founding principles of the GMG left a door open for on-site decimation of geese to reduce damage.

\subsection{Working Procedures}

Since its start, the GMG normally meets twice a year, in January and in September. At these regular meetings minutes are taken. Over the years the GMG has also made a couple of field visits to inspect crop damage and to discuss solutions on site, some of these field trips without minutes being taken. Available minutes from 23 meetings show that 65 unique individuals have attended at least one GMG meeting. Of these, 25 have only participated once (often invited for a particular purpose) and 13 individuals have taken part in 10 meetings or more (Figure 2). The first documented meeting in February 2002 was especially well attended (27 participants). At this meeting the GMG was formally established, and it was decided to devise a management plan for the Greylag goose in the GMG area. The actors to be represented in this latter group were the County Administrative Board of Scania (chairman), regional representatives of the Federation of Swedish Farmers (LRF), large private estates (farmers), the local club of the Swedish Society for Nature Conservation, the regional ornithologists association, the regional hunters' association, the local crane group, the National Swedish Wildlife Damage Centre (funded by the Swedish Environmental Protection Agency), and a representative from the Kristianstads Vattenrike Biosphere Area, as well as Kristianstad municipality.

This composition of actors invited to meetings largely remains today. The most notable changes in actors engaged in the GMG are the addition of a "goose-scarer" (Autumn 2004) to become a core instrument for practical goose management, and a game biologist from the local university college (in 2012) to add insight about the ecology of geese. 
Participation in meetings 2002-2014

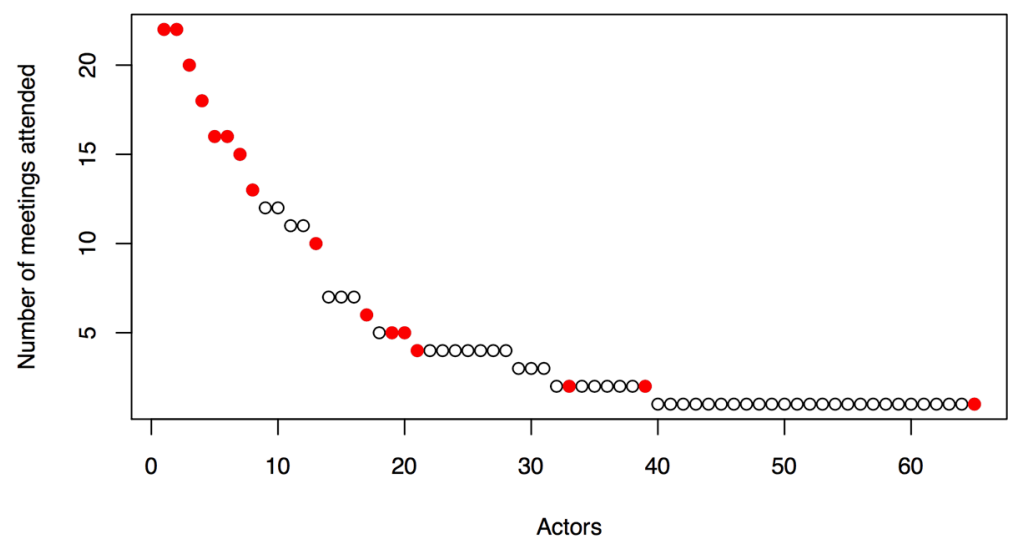

Figure 2. Participation in meetings, 2002-2014, of the Goose Management Group in North-Eastern Scania, Sweden. The plot shows the number of meetings each actor has participated in. Filled circles show the 16 actors active in the group as of 2014 and interviewed for this study. 65 actors have participated in total.

Minutes show that the GMG soon developed a meetings format with four topics discussed on almost all occasions: (1) recent monitoring results (counts) of geese; (2) current problems caused by geese; (3) solutions to reduce these problems; and (4) economics related to topics 1-3, for example crop damage cost estimates and available funding for reimbursement and goose counts. Passages of text in the minutes were coded according to this general structure, and sub-codes added for different kinds of solutions and problems. The frequency of coded passages of text (i.e., number of observations) in the minutes is:

1. Monitoring (70)

2. Problems (65)
a. Crop damage (49)
b. Miscellaneous (10)
c. Ecological (3)
d. Residual crops (3)

3. Solutions (230)
a. Hunting (67)
b. Miscellaneous (58)
c. Feeding lots (35)
d. Scaring (35)
e. Research (21)
f. Pricking of eggs (14)

4. Economy (40)

There are no set rules or statutes for how the group should operate. By their own account (interview with conveners, supported by minutes) important characteristics of the meetings have been:

- No voting-no issue has ever been resolved by voting. Voting is not part of how the group operates.

- No formal power or mandate- the group does not have any jurisdiction to decide how actors must behave or how resources are to be spent. Official administrative decisions are made by the County Administrative Board of Scania (e.g., permits for hunting outside the general public rights, reimbursements for crop damage, etc.), including ratification of the Greylag goose management plan developed by the group. 
- No formal meeting protocols-such would have to be submitted to and become part of the publicly-accessible records of the County Administrative Board of Scania. Yet, the pragmatic "minutes" format chosen provides notes from the meetings. These minutes have been freely accessible and widely distributed, not only within the GMG but also among each GMG member's network.

- GMG representatives are expected to communicate key information to their respective network. For example, farmers' representatives have informed fellow farmers that in order to be eligible for crop damage reimbursement, they should first be aware of the GMG recommendations such as: "... this is how you can prevent goose crop damage", and "... these are steps you need to take before being eligible for crop damage reimbursement". These recommendations are formulated by the GMG, and are then distributed to farmers in a workshare fashion; the Federation of Swedish Farmers duplicates and distributes the information, but postage is paid by the County Administrative Board of Scania.

- In later years, meeting minutes and recommendations to actors have also been posted on the web pages of the Kristianstads Vattenrike Biosphere Area, freely accessible.

- GMG members are free to use the information from the meetings as they wish (to their own members and to others). What actors do outside the group is not discussed or debated at meetings.

\subsection{Interviews}

The overall impression from the interviews is that the respondents view the achievements of the GMG as a resounding success. They could, with ease, explain what they are proud of and give examples of issues the group has resolved successfully (66 statements in total). Every respondent had something to suggest. In contrast, it was harder for them to provide examples of issues that have not been successfully resolved. One can suspect that particularly contentious issues are not at all brought into the GMG and, thus, that the perceived success is mostly based on "easy victories". When we asked if there are issues too sensitive to be discussed none of the respondents could think of one that had been avoided. Hunting was mentioned as a particularly sensitive issue (". . but more so in the past.") where participants have opposing views. Importantly, this topic has not been shunned and heated discussions have taken place: “... we have different opinions regarding hunting but we understand why the other side disagrees. We can joke about that.".

\subsubsection{What Makes the GMG A Success Story?}

To probe into what constitutes success in the minds of GMG members, we asked for achievements; that is, issues or problems that they are most proud of having resolved as a group. At the top of the list (mentioned by 11 respondents) is "collaboration". They specify this as being an "understanding between different interests" and how "loud people are willing to sit down" and discuss with each other. Two respondents further explain that what has been most important is not to solve any particular issue but rather having created an arena for discussion and understanding. Respondents are also proud of having instated the "goose scarer" (4 mentions), that they within the group now have more of a shared understanding of the issues (4 mentions), and that GMG has become an externally known body with some influence (3 mentions).

Respondents were also asked to give examples of more specific issues that have been discussed at the GMG meetings and subsequently resolved successfully. Most of what they mention falls under five categories:

- Compensation to farmers-a working system is now in place to handle reimbursement to farmers for crop damage.

- Feeding lots-a few designated areas with goose feed have been established to lure geese away from areas with sensitive crops. 
- "Goose scarer" - a person hired part-time by the County Administrative Board of Scania to respond to farmers' calls for assistance in scaring geese and other ways to mitigate crop damage.

- Hunting-various aspects have been addressed, e.g., increased coordination and better collaboration between hunters to increase the annual cull, policy and rules for when protective hunting can take place, and measures to increase the public demand for wild goose meat.

- Pricking of eggs-reducing the brood size of locally-breeding geese, by piercing all eggs but one in a nest, has been promoted to become a regular activity in the area.

An additional measure of success mentioned by the respondents is the respect the group now commands by local farmers and various organizations alike.

The respondents provided a variety of explanations for why the GMG is successful. To identify important abilities, or attributes, of successful local ES management respondents were asked to describe how the group has contributed to achieve the perceived success. The answers fall into nine attributes (Table 1). The most mentioned attribute was composition of the group. They asserted that the legitimacy of the GMG is grounded in the extensive experience and expertise that collectively resides within the group. Additionally, the fact that this diversity makes for better decisions by the group as "... many heads are better..." and that decisions and discussions within the GMG have a wide reach and deep penetration outside the group by virtue of it representing many and different actors.

Table 1. Explanations given (number of respondents within brackets) for why the GMG has achieved success in management of geese, coded into 9 attributes of the GMG. Based on analysis of answers to the question "What did the group contribute with (to resolve the issue)?"

\begin{tabular}{cl}
\hline Attribute & \multicolumn{1}{c}{ Explanation } \\
\hline GMG Composition (8) & The Group Represents of a Wide Variety of Actors \\
\hline Shared understanding (6) & Members of GMG pull in the same direction and work in unison. \\
\hline Dialogue (5) & $\begin{array}{l}\text { Through fruitful dialogue a shared understanding can be achieved and } \\
\text { prejudice counteracted. }\end{array}$ \\
\hline Funding (4) & $\begin{array}{l}\text { Access for actors to funding from the county and the federal authorities is } \\
\text { improved by GMG activities }\end{array}$ \\
\hline Group identity (3) & $\begin{array}{l}\text { GMG provides legitimacy to various activities, opinions are taken seriously } \\
\text { (more so than if an individual farmer speaks up) }\end{array}$ \\
\hline Respect (3) & $\begin{array}{l}\text { Within the GMG members treat each other respectfully, meaning that also } \\
\text { farmers not part of the group feel that they are listened to (thus contributing } \\
\text { to a more respectful attitude between actors in general). }\end{array}$ \\
\hline External relationships (3) & $\begin{array}{l}\text { GMG has obtained good and fruitful relationships with others, e.g., the } \\
\text { County Administrative Board of Scania, farmers and local business. }\end{array}$ \\
\hline Compromise (2) & $\begin{array}{l}\text { Searching for and finding a compromise has resolved contested issues, the } \\
\text { ability to see issues "from both sides" creates a "balanced discussion" }\end{array}$ \\
\hline Neutral arena (1) & $\begin{array}{l}\text { Having the meetings on neutral ground (meeting facilities provided by the } \\
\text { County Administrative Board of Scania) helps to defuse conflicts. }\end{array}$ \\
\hline
\end{tabular}

Respondents point out that the GMG has moved actors from a highly-conflicted situation to a present one of shared understanding. The general problem-solving procedure in the GMG is described as a three-step process: first a problem is identified; secondly, difficulties and possibilities are discussed; and, thirdly, an agreement is reached regarding how to proceed. One respondent mentions that this shared understanding "... makes one feel safe-that this [whatever solution to a problem the group decides on] could be a way forward.", another comments that in order to move forward "... we must resolve issues in a way so that all parties are content".

The dialogue, the discussions, are mentioned as essential for success-“... it has worked and been accepted by all because we have been able to discuss difficulties and possibilities and reach a 
shared understanding.". Respondents mention the respectful dialogue, successful discussions, and the ability to moderate opposing interests within the group. Through this "... one discovers that the common ground is bigger than the opposing interests" and that in this way one "... counteracts prejudice and bias". A long-standing member of the group is singled out as being particularly good at maintaining factual and unbiased discussions and, thus, defusing conflicts.

\subsubsection{What Issues Have Not Been Successfully Resolved?}

When asked to give examples of issues that have been discussed at GMG meetings but subsequently not successfully resolved, most respondents could not come up with a single such example. When pressed for an answer, the question repeated, some of them provided examples (25 statements in total). The second-most common answer after "I can't think of one" was the fact that GMG has failed to limit the increase in the number of geese in the region, although it has been successful in reducing crop damage (8). Hunting is also mentioned as an issue not having been successfully resolved (5): “. . people don't know how to hunt them. . ", “... want a general open hunting [regarding Barnacle goose] season but EU directives [make this impossible]... " and "... the protective hunting [by special permit] now allowed is there to constrain farmers from getting compensation for crop damage... ".

Most of the answers given (21 of 33) fall under the aforementioned three categories. Beyond these a variety of unresolved issues were identified: designated feeding lots-there needs to be more of them to draw geese away from sensitive crops; collaboration — not every farmer in the area is on-board wholeheartedly; compensation - the GMG does not have a clear position on when reimbursements should be given; ecological impact in lakes-geese grazing are reducing stands of Bulrush Scirpus spp. and potentially contributing to eutrophication by their droppings; and follow up-GMG should better follow up and evaluate its activities.

The difficulty in establishing an additional goose management group, in Southwest Scania, is mentioned in the context of failure but at the same time respondents explain that this is not truly a responsibility of the GMG.

\subsubsection{What Are the Reasons Behind a Lack of Success?}

We find four reasons why the GMG did not succeed in resolving certain issues discussed at its meetings. First - the (lack of official) mandate of the group is mentioned as a limiting factor. The respondents note that farmers participate on a voluntary basis in initiatives from the GMG. The group can not force compliance when e.g., orchestrating coordinated hunting in an area (as uncoordinated hunting may lead to geese only moving around in the landscape) or when trying to find suitable land and willing farmers for establishing goose feeding lots. Secondly, lack of shared understanding, that there are still opposing views on some issues, can impede decisive actions from being taken. The high level of shared understanding within the GMG—or rather the trust within it—is also mentioned as a possible reason to why follow up and evaluation of decisions made by the group are not done as rigorously as they perhaps should be.

A third limiting factor is available resources in terms of time and personnel, rather than lack of funding, "... a difficult and labour-intensive issue that takes time is to find common ground [relating to hunting] because there are so many landowners..." Lastly, lack of know-how is mentioned. One respondent concludes that there is no blueprint to follow for what they do, and there is very little experience from other parts of the country to take advantage of, and this leads to mistakes at times.

\subsubsection{Is the GMG Satisfied with Its Mandate and Composition?}

The group is not seeking to change or expand its mandate. As one member states: "The group was not created to make decisions... but to create collaboration and together help in finding solutions." To elicit a wish list from the GMG interviewees were asked "What is the thing you most of all would like to be able to decide over that you cannot today?" "Better funding" for the group and "higher 
compensation to farmers" were mentioned. Seven respondents discussed hunting in their reply, indicating that this is an area where they are not completely happy with present regulation and decision-making, e.g., that they do not have influence over hunting in other countries. However, the respondents also acknowledge that it would not necessarily be a good idea, all things considered, that this should be under GMG jurisdiction.

There was an agreement among the respondents that the composition, and size, of the GMG is satisfactory. It was suggested, though, that stronger presence by owners of larger estates and the inclusion of professional hunters could strengthen the group further. It was also mentioned that the members are getting older and that younger members would be an asset.

\section{Discussion and Implications}

\subsection{Is the Goose Management Group Successful?}

According to its members the GMG is a resounding success. They refer to a string of achievements over the years such as having developed a system that works to compensate farmers for crop damage, the introduction of a "goose scarer" and the testing of feeding lots (to move geese to designated areas) and pricking of eggs (to reduce reproductive success) to reduce crop damage. These activities were all first tested and then scaled up as they showed promise. This is in line with adaptive management-an approach in which tight feedback between management action and ecosystem response, or ecosystem change, is emphasized [21]. Adaptive management is a well-established approach with proven efficacy [37] though it is important to note that delineating what counts as adaptive management, and how to measure success, may confound cross-case comparisons (see e.g., [38,39]).

However, though clearly an important feature, it is not the ability of the group to be adaptive that is the defining characteristic of the GMG. Above all, its success lies in establishing a collaborative arena for sharing experiences and addressing problems, justifying that the GMG is better described as an example of adaptive co-management. When describing what the GMG has contributed with that explains its success all answers given, with the exception of funding, are 'soft properties' that are supportive of effective collaboration. These include establishing a shared understanding, dialogue, a group identity, respect between actors, and the ability to compromise. Thus, the success is described by the group more in terms of improved management or governance rather than improved outcome of such management. Interestingly, a recent review of learning in adaptive management shows that $1 / 4$ of the cases listed "improved governance" as a stated goal but as much as $3 / 4$ of them in the end reported it as an achievement [40]. In our case "collaboration" is what the group is most proud of. Notably, the GMG never had an explicit quantitative goal to reduce crop damage nor, as a goal, to reduce the number of geese in the landscape as a whole. What the GMG has succeeded in instead is reducing conflicts, triggered by geese, between actors.

In addition, access for actors to funding from county and national authorities has been facilitated by the GMG. This is true for both reimbursements for crop damage and activities promoted by the GMG. Reimbursement for crop damage is conditioned to participation by farmers in activities that aim at reducing crop damage (such as collaboration with the "goose scarer"). This is far from payments for ES based on a monetary valuation of having geese in the landscape (a seller-buyer relationship). It is better described as a "fair reward for acting responsibly" [41]. The funding to test the effectiveness (and feasibility) of activities suggested by the GMG, such as egg pricking, fences, feed lots, and the "goose scarer" is in line with what Muradian and Rival [13] describes as incentives "... that may become the 'tipping point' in changing practices and behaviour". It is not subsidies to specific actors, but rather investments for the common good, as identified and advocated for by the GMG.

\subsection{Which Problems Are Solved and Which Remain?}

In this section we re-address the four general challenges to ES management outlined in the Introduction and investigate how well the GMG is suited to address these. We do this by deconstructing 
the management solution that the GMG represent into nine attributes and discuss these in relation to the challenges.

Challenge (1): It is the realization that trade-offs occur that initiated the forming of the GMG. The composition of the group and the ability to make use of knowledge and expertise from different fields (see Table 2) are the institutional features of the GMG that help identify trade-offs.

Table 2. How key attributes (left column) of the Goose Management Group (GMG), identified as attributing to the group's success by its members, address four key challenges of management of ecosystem services (panel on top, see Introduction).

\begin{tabular}{|c|c|c|c|c|}
\hline $\begin{array}{l}\text { Key Challenges } \\
\text { Addressed by } \\
\text { Attributes of } \\
\text { the GMG }\end{array}$ & $\begin{array}{l}\text { Identification of } \\
\text { Trade-Offs }\end{array}$ & $\begin{array}{c}\text { Mediation of } \\
\text { Opposing Preferences }\end{array}$ & $\begin{array}{l}\text { Responding to } \\
\text { Temporal and } \\
\text { Spatial Variability }\end{array}$ & $\begin{array}{c}\text { Recognition of } \\
\text { System Complexity }\end{array}$ \\
\hline GMG composition & $\begin{array}{l}\text { takes wide } \\
\text { variety of actors } \\
\text { into account }\end{array}$ & $\begin{array}{l}\text { gives legitimacy and } \\
\text { wide reach to actors in } \\
\text { the landscape }\end{array}$ & $\begin{array}{l}\text { provides monitoring } \\
\text { and capability to act in } \\
\text { various places in the } \\
\text { landscape when needed }\end{array}$ & $\begin{array}{l}\text { adds expertise and } \\
\text { brings multiple views } \\
\text { to the table }\end{array}$ \\
\hline $\begin{array}{c}\text { Shared } \\
\text { understanding }\end{array}$ & & $\begin{array}{l}\text { helps to pull in the } \\
\text { same direction }\end{array}$ & & $\begin{array}{l}\text { helps to embrace } \\
\text { complexity and work in } \\
\text { unison to co-ordinate } \\
\text { complementary } \\
\text { activities across } \\
\text { the landscape }\end{array}$ \\
\hline Dialogue & & $\begin{array}{l}\text { promotes shared } \\
\text { understanding }\end{array}$ & & $\begin{array}{c}\text { counteracts } \\
\text { simplification, prejudice } \\
\text { and bias }\end{array}$ \\
\hline Funding & & $\begin{array}{l}\text { enables reimbursements } \\
\text { for crop damage and } \\
\text { e.g., establishing feeding } \\
\text { lots and a goose scarer }\end{array}$ & $\begin{array}{l}\text { supports goose counts } \\
\text { describing variability }\end{array}$ & \\
\hline Group identity & & $\begin{array}{l}\text { gives legitimacy in the } \\
\text { eyes of authorities and } \\
\text { local actors }\end{array}$ & & \\
\hline Respect & & $\begin{array}{l}\text { promotes constructive } \\
\text { dialogue in the group }\end{array}$ & $\begin{array}{l}\text { actors distributed in the } \\
\text { landscape feel listened } \\
\text { to and inclined } \\
\text { to collaborate }\end{array}$ & \\
\hline $\begin{array}{l}\text { External } \\
\text { relationships }\end{array}$ & & $\begin{array}{l}\text { enables collaboration } \\
\text { and support }\end{array}$ & & $\begin{array}{l}\text { provides increased } \\
\text { funding and support to } \\
\text { turn ideas into actions }\end{array}$ \\
\hline Compromise & & $\begin{array}{l}\text { contributes to resolving } \\
\text { contested issues by } \\
\text { finding common ground }\end{array}$ & & \\
\hline Neutral arena & & $\begin{array}{l}\text { relaxed atmosphere at } \\
\text { meetings, sets the tone } \\
\text { of discussions }\end{array}$ & & \\
\hline
\end{tabular}

Challenge (2): The main problem solved by the GMG, is a reduction of goose-human conflicts, i.e., the challenge of opposing preferences, vis-à-vis geese in the landscape. When first listening to GMG members one might draw the conclusion that its modus operandum is to establish consensus in all issues discussed. This would be erroneous in our opinion, as a critical feature is rather an ability of the group to, over an extended period of time, continue to exchange opinions and ideas. Susskind and co-workers [42] noted that "Despite the establishment of a multistakeholder forum, the creation of a scientific data centre and the provision of considerable resources..." the collaborative adaptive management initiative they studied failed to get broad support. They conclude that this was mainly because of "poor design of the collaborative process" and suggest that success depends heavily upon 
the ability to facilitate participation and foster collaboration. Table 2 illustrates that the majority of the key attributes of the GMG is geared towards this challenge.

Challenge (3): The GMG has been successful in orchestrating landscape-wide activities, such as goose counts and creating feeding lots to move geese to designated areas. The actions taken by the group have targeted fast changing variables-the variability in the number of geese at certain parcels of land within the landscape and from one day to another. The GMG was formed rather as a response to a slowly changing variable, the yearly increase in the number of geese on agricultural land at times when they can inflict damage to crops (Figure 1). The elephant in the room is that there is no indication that overall goose abundance at the landscape level has been countered by the GMG. Thus, crop damage may increase in the future with exacerbated conflicts between actors.

Challenge (4): Complex challenges are ill-met by simplistic institutional arrangements. The GMG is a simple solution to a management problem, but not a simplistic one. The group is allowed to set its agenda, invite new members, and pursue solutions to problems as they see fit. The GMG has autonomy to self-organize. Hahn [28] suggested there is a conflict between accountability and adaptability that is particularly prominent in management of ES. This is because such management must build on "flexibility, adaptability, and innovation, which are all enabled by self-organized networks, while at the same time maintaining the accountability of elected democratic bodies." The GMG circumvents this by not being formally accountable and "only" acting as an advisory group for the County Administrative Board. As such, the GMG does not have to carry the burden of potentially contentious decisions (e.g., the total budget allocated to farmers as reimbursement for crop damage, or rules regarding hunting). Importantly, decisions by the County Administrative Board follow closely the advice provided by the GMG.

\subsection{Can the GMG Serve As a Model for Management of Other ES in other Landscapes?}

Interestingly, the GMG is a bottom-up initiative in a domain where management historically has rather been initiated and implemented from the opposite end of governance hierarchy and spatial scale, i.e., in a top-down fashion. For example, in Canada and the USA the shared populations of migratory geese have long been managed at the continental (flyway) level, by means of bi-lateral federal agreements, treaties, and legislation.

We understand the GMG as a kind of "hand-shake-management" that rests heavily on personal relationships, establishing of trust among actors, mutual respect, and gaining experience through shared learning. The GMG is set in a collective action context (geese move freely in the landscape, demanding coordinated and collective actions) and finding solution to social dilemmas (where actors' preferences stand against each other) is helped by the establishment of social norms and a shared understanding of appropriate actions (see e.g., [43]). This building of expertise within the GMG, and the group's ability to orchestrate activities and communication among actors in the landscape, are prioritized over defining and establishing procedural rules. Klein [44] suggested that prioritizing expertise gained through experience should be considered when faced with decision-making in ambiguous, highly-complex circumstances.

In the sense that the GMG does address general challenges to ES management (Table 2)-the key attributes of the GMG are not specific to management of geese- the group can indeed serve as inspiration for ES management in other settings and of other ES. It is, however, important to also consider the specific context, and in the case of the GMG we observe three conditions that may have been instrumental to its success: (1) appropriate leadership is very important [45] and also mentioned by our respondents. The leadership within the GMG can draw on personal experiences with previous success in collaborative management and wider governance (the creation of the Kristianstads Vattenrike Biosphere Area [32]; (2) the crane group, predecessor of the GMG, provided a proof of concept in the eyes of actors, such as farmers and ornithologists, and also in the eyes of government authorities; (3) the close relationship between the highly self-directed GMG and the legally-responsible regional authority is enhanced by members with legs in both camps. 
This case study also provides critical arguments why an approach as that of the GMG may not work under certain circumstances or in other settings:

- It takes time to establish a working collaborative arena—time that may not be available if conflicts call for urgent action.

- Actors may be transient in the landscape or in their respective organization, limiting the ability to establish key features and abilities (Table 2) characterizing the GMG.

\subsection{Limitations of the Study}

The primary dataset used for our analysis of the GMG is accounts from members of the group; their observations and their conclusions. In this study we have not tested the validity of their statements. To some degree this could be achieved by interviews or surveys to a larger sample of actors, of which the GMG members are representatives (e.g., farmers, hunters, landowners). Further, it would be useful to understand if there are differences in how actively GMG members have represented their group's opinions, or if the degree of satisfaction differs among stakeholders. Our study was not designed to address these issues, but based on the available sample we see no obvious trend at least in satisfaction among stakeholder groups, again highlighting the perceived successful collaboration.

\subsection{Future directions}

The GMG case represents an interesting mix of actors in a couple of ways. Firstly, their respective "stakes" differ significantly and represent currencies rather incommensurable in the eyes of many. Farmers, for example, can lose substantial sums due to goose grazing, but the monetary value of losses is fairly easy to estimate. Ornithologists, on the other hand, face problems as soon as they wish to measure the value of geese to them. Secondly, the fact that the GMG comprises a mix of representatives for both local and regional (province/county) interests is interesting, and hinges back to the issues of scale developed above. We hypothesize that a combination of local embeddedness (e.g., land owners, bird club) and province/county foothold (county administrative board, conservationists, Scania hunters' federation) increases legitimacy and provides a de facto "subsurface" accountability (cf. [28]), both of which serve to defuse conflict, build connections of trust, and enable action. We argue that scale issues in management of common ES, not the least migratory game, deserve deeper scientific study. As a case in point, the GMG begs the question of what "a landscape" actually is in terms of ES management [46].

When combining minutes with interviews we notice considerable differences in information flow within actor groups. Farmers seem more active in spreading information from the GMG among themselves locally than are ornithologists and hunters. From a vertical perspective, another intriguing pattern emerges; when ornithologists and hunters meet in the GMG they seem to have less of a hard time to discuss freely and understand each other, compared to when representatives for the very same organizations meet at the national level. These were unexpected examples of vertical-horizontal asymmetry in information sharing and, indirectly, in identification of trade-offs and mediation of opposing preferences (cf. Table 2). Existence, patterns and process of such asymmetries warrant deeper study in ES research, especially with respect to multilevel systems (cf. [32]).

In a review of two decades of research into managing the commons, Berge and van Laerhoven [47] observed that global commons, on the one hand, and local/regional commons, on the other, are very different things and then, one might ask, what is the value of cross case comparisons? The GMG provides a successful example of a local management solution that can also be described as a failure by not addressing continental drivers behind the trend of increasing populations of some species. When - and to what extent-locally tested solutions, or rather a set of particular features or attributes of these, can be scaled up is an important direction of research in management of ES. If management of ES is indeed more about managing human relationships than about managing ecosystems ( $c f$. [40]) one might ask: in what way are identified attributes associated with the mediation of conflicts between actors dependent on scale? —or in other words—how far can a handshake travel? 


\section{Conclusions}

In this article we investigate a local management solution, the Goose Management Group (GMG), to alleviate goose-human conflicts in a productive agricultural region in Southern Sweden. The GMG is a simple, but not simplistic, answer to a complex problem. We observe that the GMG is adaptive, can react quickly to signals from the system, has continuity over time and is embedded in the landscape in which it is working. It is successful in defusing conflict at the local level, although goose population growth, legislative change, and conservation are processes primarily occurring at national and international levels. The model, thus offers promise to be a sustainable management solution.

The GMG is viewed as a success by actors in the landscape. We conclude that success of the GMG lies in establishing a collaborative arena for sharing experiences and addressing problems. We identify attributes explaining the success of the GMG and point out that the main achievements pertain to reduced perceived reduction of conflicts, triggered by geese, between actors rather than a success in reducing the number of geese on the landscape. We note that seasonally-variable multi-species assemblages of migratory geese is an example where local challenges, and the success of local actions to address the ecology of the ES, hinge strongly on processes occurring in other landscapes, more or less distant.

We suggest that mapping attributes of the management solution to general challenges of ES can inform on the value of cross case comparisons.

Supplementary Materials: Supplementary Materials are available online at www.mdpi.com/2071-1050/7/12/ 15794/s1.

Acknowledgments: The members of GMG, in particular Hans Cronert and Anders Hallengren, are sincerely thanked for information and discussions. We thank Rebecca Hessel and Peter Bengtsson for bibliographical help. Thomas Beery provided insightful comments on previous versions of this text. This study was supported by grants NV-01518-13 and NV-01740-14 from the Swedish Environmental Protection Agency to Johan Elmberg and by Kristianstad University through funding to the Man and Biosphere Health (MABH) research platform.

Author Contributions: Magnus Tuvendal and Johan Elmberg together developed the study idea, collected the data and wrote the manuscript. Magnus Tuvendal did most of the analyses of the interviews. Magnus Tuvendal and Johan Elmberg prepared and approved the manuscript.

Conflicts of Interest: The authors declare no conflict of interest.

\section{References}

1. Haines-Young, R.; Potschin, M. The links between biodiversity, ecosystem services and human well-being. In Ecosystems Ecology. A New Synthesis; Frid, C.L.J., Ed.; Cambridge University Press: Cambridge, UK, 2010; pp. 110-139.

2. Andersson, E.; McPhearson, T.; Kremer, P.; Gomez-Baggethun, E.; Haase, D.; Tuvendal, M.; Wurster, D. Scale and context dependence of ecosystem service providing units. Ecosyst. Serv. 2015, 12, 157-164. [CrossRef]

3. Kareiva, P.; Tallis, H.; Ricketts, T.H.; Daily, G.C.; Polasky, S. Natural Capital: Theory and Practice of Mapping Ecosystem Services; Oxford University Press: Oxford, UK, 2011.

4. Derkzen, M.L.; van Teeffelen, A.J.A.; Verburg, P.H. Quantifying urban ecosystem services based on high-resolution data of urban green space: An assessment for Rotterdam, the Netherlands. J. Appl. Ecol. 2015, 52, 1020-1032. [CrossRef]

5. Daily, G.; Söderqvist, T.; Aniyar, S.; Arrow, K.; Dasgupta, P.; Ehrlich, P.; Folke, C.; Jansson, A.; Jansson, B.-O.; Kautsky, N.; et al. The Value of Nature and the Nature of Value. Science 2000, 289, 395-396. [CrossRef] [PubMed]

6. Martín-López, B.; Gómez-Baggethun, E.; García-Llorente, M.; Montes, C. Trade-offs across value-domains in ecosystem services assessment. Ecol. Indic. 2014, 37, 220-228. [CrossRef]

7. Gómez-Baggethun, E.; de Groot, R.; Lomas, P.L.; Montes, C. The history of ecosystem services in economic theory and practice: From early notions to markets and payment schemes. Ecol. Econ. 2010, 69, 1209-1218. [CrossRef] 
8. The Economics of Ecosystems and Biodiversity (TEEB). The Economics of Ecosystems and Biodiversity: Mainstreaming the Economics of Nature: A Synthesis of the Approach, Conclusions and Recommendations of TEEB; TEEB: Geneva, Switzerland, 2010.

9. Martinez-Harms, M.J.; Bryan, B.A.; Balvanera, P.; Law, E.A.; Rhodes, J.R.; Possingham, H.P.; Wilson, K.A. Making decisions for managing ecosystem services. Biol. Conserv. 2015, 184, 229-238. [CrossRef]

10. Cox, M.; Arnold, G.; Tomás, S.V. A review of design principles for community-based natural resource management. Ecol. Soc. 2010, 15, 38.

11. Rogers, K.H.; Luton, R.; Biggs, H.; Biggs, R.; Blignaut, S.; Choles, A.G.; Palmer, C.G.; Tangwe, P. Fostering complexity thinking in action research for change in social-ecological systems. Ecol. Soc. 2013, 18, 31.

12. Schröter, M.; van der Zanden, E.H.; van Oudenhoven, A.P.E.; Remme, R.P.; Serna-Chavez, H.M.; de Groot, R.S.; Opdam, P. Ecosystem services as a contested concept: A synthesis of critique and counter-arguments. Conserv. Lett. 2014, 7, 514-523. [CrossRef]

13. Muradian, R.; Rival, L. Between markets and hierarchies: The challenge of governing ecosystem services. Ecosyst. Serv. 2012, 1, 93-100. [CrossRef]

14. Elmqvist, T.; Tuvendal, M.; Krishnaswamy, J.; Hylander, K. Ecosystem services-Managing trade-offs between provisioning and regulating services. In Valuation of Regulating Services of Ecosystems: Methodology and Applications; Pushpam, K., Wood, M.D., Eds.; Taylor \& Francis Ltd.: London, UK, 2010.

15. Bradbury, R.B.; Stoate, C.; Tallowin, J.R.B. Lowland farmland bird conservation in the context of wider ecosystem service delivery. J. Appl. Ecol. 2010, 47, 986-993. [CrossRef]

16. Richnau, G.; Angelstam, P.; Valasiuk, S.; Zahvoyska, L.; Axelsson, R.; Elbakidze, M.; Farley, J.; Jönsson, I.; Soloviy, I. Multifaceted value profiles of forest owner categories in South Sweden: The River Helge å catchment as a case study. Ambio. 2013, 42, 188-200. [CrossRef] [PubMed]

17. Fisher, B.; Turner, R.; Morling, P. Defining and classifying ecosystem services for decision making. Ecol. Econ. 2009, 68, 643-653. [CrossRef]

18. Holling, C.S.; Meffe, G.K. Command and control and the pathology of natural resource management. Conserv. Biol. 1996, 10, 328-337. [CrossRef]

19. Burns, T.R.; Stöhr, C. Power, knowledge, and conflict in the shaping of commons governance. The case of EU Baltic fisheries. Int. J. Commons 2011, 5, 233-258. [CrossRef]

20. Reid, W.V.; Harold, A.; Mooney, A.C.; Capistrano, D.; Carpenter, S.R.; Chopra, K.; Dasgupta, P.; Dietz, T.; Duraiappah, A.K.; Hassan, R.; et al. Millennium Ecosystem Assessment: Synthesis Report; Island Press: Washington, DC, USA, 2005.

21. Holling, C.S. Adaptive Environmental Assessment and Management; John Wiley and Sons: New York, NY, USA, 1978.

22. Armitage, D.; Marschke, M.; Plummer, R. Adaptive co-management and the paradox of learning. Glob. Environ. Chang. 2008, 18, 86-98. [CrossRef]

23. Allan, C.; Stankey, G.H. Adaptive Environmental Management: A Practitioner's Guide; CSIRO Publishing: Clayton, Australia, 2009.

24. Kofinas, G.P. Adaptive Co-management in Social-Ecological Governance. In Principles of Ecosystem Stewardship: Resilience-Based Natural Resource Management in a Changing World; Chapin, F.S., III, Kofinas, G.P., Folke, C., Eds.; Springer: New York, NY, USA, 2009; pp. 77-101.

25. Madsen, J.; Williams, J.H. International Species Management Plan for the Svalbard population of the Pink-footed Goose Anser brachyrhynchus; AEWA Technical: Bonn, Germany, 2012.

26. Green, A.J.; Elmberg, J. Ecosystem services provided by waterbirds. Biol. Rev. 2013, 89, 105-122. [CrossRef] [PubMed]

27. Angelstam, P.; Grodzynskyi, M.; Andersson, K.; Axelsson, R.; Elbakidze, M.; Khoroshev, A.; Kruhlov, I.; Naumov, V. Measurement, collaborative learning and research for sustainable use of ecosystem services: Landscape concepts and Europe as laboratory. Ambio 2013, 42, 129-145. [CrossRef] [PubMed]

28. Hahn, T. Self-organized governance networks for ecosystem management: Who is accountable? Ecol. Soc. 2011, 16, 18.

29. Tuvendal, M.; Elmqvist, T. Ecosystem services linking social and ecological systems: River brownification and the response of downstream stakeholders. Ecol. Soc. 2011, 16. [CrossRef]

30. Nekoro, M., Svedén, J., Eds.; Ekosystemtjänstanalys I Kristianstads Vattenrike; Report 5947; Swedish Environmental Protection Agency (Naturvårdsverket): Stockholm, Sweden, 2009. 
31. Schultz, L.; Folke, C.; Olsson, P. Enhancing ecosystem management through social-ecological inventories: Lessons from Kristianstads Vattenrike, Sweden. Environ. Conserv. 2007, 34, 140-152. [CrossRef]

32. Olsson, P.; Folke, C.; Galaz, V.; Hahn, T.; Schultz, L. Enhancing the fit through adaptive co-management: Creating and maintaining bridging functions for matching scales in the Kristianstads Vattenrike Biosphere Reserve, Sweden. Ecol. Soc. 2007, 12, 28.

33. Nordöstra Skånes Fågelklubb (Bird Club of Northeastern Scania). Available online: http:/ /www.spoven.com/ index.php?option=com_content\&view=category\&layout=blog\&id=18\&Itemid=14 (accessed on 12 June 2014).

34. Thomas, D.R. A general inductive approach for analyzing qualitative evaluation data. Am. J. Eval. 2006, 27, 237-246. [CrossRef]

35. Leech, B. Asking questions: Techniques for semistructured interviews. Polit. Sci. Polit. 2002, 35, 665-668. [CrossRef]

36. Edberg, R. Förvaltningsplan för Grågås (Management Plan for Greylag Goose); Länsstyrelsen i Skåne län, Miljöenheten, Naturresursfunktionen: Kristianstad, Sweden, 2003.

37. Kenward, R.E.; Whittingham, M.J.; Arampatzis, S.; Manos, B.D.; Hahn, T.; Terry, A.; Simoncini, R.; Alcorn, J.; Bastian, O.; Donlan, M.; et al. Identifying governance strategies that effectively support ecosystem services, resource sustainability, and biodiversity. Proc. Natl. Acad. Sci. USA 2011, 108, 5308-5312. [CrossRef] [PubMed]

38. Rist, L.; Campbell, B.M.; Frost, P. Adaptive management: Where are we now? Environ. Conserv. 2013, 40, 5-18. [CrossRef]

39. Allen, C.R.; Fontaine, J.J.; Pope, K.L.; Garmestani, A.S. Adaptive management for a turbulent future. J. Environ. Manag. 2011, 92, 1339-1345. [CrossRef] [PubMed]

40. Fabricius, C.; Cundill, G. Learning in adaptive management: Insights from published practice. Ecol. Soc. 2014, 19, 29. [CrossRef]

41. Vatn, A. An institutional analysis of payments for environmental services. Ecol. Econ. 2010, 6, 1245-1252. [CrossRef]

42. Susskind, L.; Camacho, A.E.; Schenk, T. A critical assessment of collaborative adaptive management in practice. J. Appl. Ecol. 2012, 49, 47-51. [CrossRef]

43. Meyfroidt, P. Environmental cognitions, land change, and social-ecological feedbacks: An overview. J. Land Use Sci. 2013, 8, 341-367. [CrossRef]

44. Klein, G. Streetlights and Shadows: Searching for the Keys to Adaptive Decision Making; MIT Press: Cambridge, MA, USA, 2009.

45. Westley, F. The devil in the dynamics: Adaptive management on the front lines. In Panarchy: Understanding Transformations in Human and Natural Systems; Gunderson, L.H., Holling, C.S., Eds.; Island Press: Washington, DC, USA, 2002; pp. 333-360.

46. Setten, G.; Stenseke, M.; Moen, J. Ecosystem services and landscape management: Three challenges and one plea. Int. J. Biodivers. Sci. Ecosyst. Serv. Manag. 2012, 8, 305-312. [CrossRef]

47. Berge, E.; van Laerhoven, F. Governing the Commons for two decades: A complex story. Int. J. Commons 2011, 5, 160-187. [CrossRef]

(C) 2015 by the authors; licensee MDPI, Basel, Switzerland. This article is an open access article distributed under the terms and conditions of the Creative Commons by Attribution (CC-BY) license (http://creativecommons.org/licenses/by/4.0/). 